\title{
Persuasion and the Online Consumers: Investigating Copywriting Strategies in Native Advertisements
}

\author{
Hani Zulaikha Zulkifly and Norsham Firdaus
}

\begin{abstract}
This study aims at analysing the copywriting strategies of slimming product advertisements in determining consumers' information seeking action. The study was conducted qualitatively via a focus group. Women who actively seek for slimming products in Facebook were selected through the purposive sampling technique. The findings indicated that most of the informants were attracted to read the body copy of the advertisements because of the unique headlines as well as the use of striking, contrasting colours for fonts and the background. Testimonials, the word 'repeat order' and language usage on the other hand were elements that enhanced the informants' interest towards the native advertisements. Most importantly, the desire to own the advertised products came after the informants saw the believable comparative pictures and weight reduced text which then stimulates them to click on the advertisements' Facebook pages to look for more details about the products. Nevertheless, some of the informants ignored some of the advertisements shown to them because they doubted the product's unique selling proposition (USP). Provocation statements in the advertisements, on the other hand were perceived as unfavourable among the informants, thus led them not to click on its' Facebook page.
\end{abstract}

Index Terms-AIDA model, copywriting strategies, information seeking action, native advertisements, online consumers.

\section{INTRODUCTION}

Consumer's purchase intention is the most sought after outcome among marketers once they have invested to promote their products and services. Purchase intention for the most part depends on consumer's level of involvement with the advertised products since the persuasive messages will be processed in the central route [1]. However, the highly involved consumers may not recognize the advertisement without adequate attraction to lead the action. As to capture the attention of online consumers towards the promoted products and services, most marketers chose to use the interruptive advertising strategies. The banners, popup ads, trueview ads and the in-stream ads are the examples of online advertisements that ironically forcing the consumers to view the promoted products and services. Although the consumers have the absolute power to skip some of the advertisements, these interruptive strategies are likely to convey negative perception among the consumers towards the product brands.

Apparently, this is why marketers would prefer to

Manuscript received July 20, 2013; revised September 21, 2013.

Hani Zulaikha Zulkifly is with the Faculty of Arts and Social Sciences, Universiti Malaya (UM), Malaysia (e-mail: hani_zulaikha@ymail.com).

Norsham Firdaus is with the Faculty of Communication and Media Studies, Universiti Teknologi MARA, Shah Alam, Malaysia (e-mail: sham1505@salam.uitm.edu.my). advertise their products and services natively in which the consumers can choose to watch only advertisements they want to see. Native advertisements are the non-interruptive advertisements, integrated endemically with the website contents [2]. In Facebook for instance, native advertisements exist as the 'Suggested Posts' and 'Sponsored Stories'. Native advertising has illustrated positive impact on consumers' brand recall, brand awareness, brand favourability and purchase intent [3]. This might be the basis for many people who predicted that native advertising would be the marketing trend in 2013 [4], [5]. Despite the positive side of native advertisement, it is found that less than 40 percent of the respondents find native advertisements attracted their attention and lead them to click it [3].

Primarily, it is important for an advertisement to attract the potential customers' attention in order to lead action [6], [7]. If the native advertisements appeared less eye-catching to respondents, the advertisements in other words are less likely to promote consumers' action. Consequently, the marketers' sales objectives could not be achieved.

Although the interruptive advertising is said to communicate negative meanings towards the product brand, trueview ads at least managed to capture the audiences' attention in the first five seconds before the audiences are able to skip the advertisement. It is found that 90 percent of the respondents continued watching the advertisement rather than skipping it because they were curious to know what the advertisement is all about [8].

In contrast, the nature of native advertising seemingly has reduced the potential of an advertisement to be seen by consumers. Rather, the native advertisements are targeted only to the highly involved consumers who feel that they are related to the product or brand.

The AIDA model has indicated four stages in advertising [7]. An advertisement should primarily create attention/awareness, generate interest and desire among the consumers towards the product. Then only the advertisement would call for action. This illustrates the essentialness of an advertisement to attract and hold consumer's attention in order to lead them to act.

Since native advertisement is based on consumer's decision to click, therefore, this study aims to explore the persuasive copywriting strategies of native advertisements in leading consumer's information seeking action towards the advertised products.

The objectives of this study are:

1) To identify important persuasive elements in native advertisements of slimming products

2) To explore how elements of native advertisements lead the informants to seek for more information about the 
advertised products

3) To identify elements of native advertisements that would obstruct the informants from searching for more information about the advertised products

\section{Characteristics of A Persuasive Message}

Essentially, an advertisement should encompass elements that complement each other in conveying the message. Visual aspects of an advertisement for instance have to be connected to the body copy and headlines [9]. Generally, both pictures and headlines could lead the consumers to read the body copy [9]. In fact, pictures could send a particular message faster than the words do [10].

Slimming products' advertisements frequently use comparative pictures portraying a model before and after using or consuming the advertised products. Therefore, the believability of the pictures is important since slimming products involve consumers' cost in terms of money spent, time consumption and expectation of the result. Consumers could also be misled into believing that a model looks slimmer than the real one with the manipulation of the pictures using photo editing software.

Moreover, some comparative pictures only include the body, without the model's face. This may increase the irrelevant thoughts among consumers. Therefore, pictures are important element in an advertisement since it could actually convey the relevancy of the product information [9]. Thus, pictures could impact informants' brand attitude [11].

Headlines, on the other hand should represent the whole advertising message [12]. As for the colour usage, intense colour grabs attention [13]. Hence, the use of powerful colour for the headlines is an important aspect that can add visual impact and attract the attention of consumers.

Testimonials could bring positive attitude towards the brand as it entails people's product experience which enhances the credibility of the advertising messages [14]. Testimonials at most of the time would use narration either by the product users or by their friends, telling others of how things differ after using or consuming the advertised product [9].

The use of successful slice-of-life advertisements could also lead to the effectiveness of an advertisement. A simple, memorable and realistic one should be applied as it could briefly tell the benefits of the product as well as motivating the consumers to buy and try [9].

In addition, language usage in advertisement has to be acceptable among consumers [15]. It means that an advertisement should be sensitive to its targeted audience regardless of sex, age, race and culture.

Advertising message strategy usually combines the rational and emotional appeals because consumers' decisions are mostly determined by their rational and emotional motives [9]. Recently, scholars found that the impact of a persuasive message could be increased by focusing on the personality traits [16].

In essence, advertisement has to persuade and reassure the consumers that their decision to buy the advertised product is correct [17]. Additionally, deceptive advertising should be avoided since there is significant association between exposure to deceptive advertising and the low probability of consumption [18].

\section{Methodology}

The study has been conducted qualitatively via a focus group of 15 women. They were selected as the informants merely because it is observed that they clicked 'like' at the 'suggested post' regarding slimming products in Facebook. Their action for clicking 'like' to the 'suggested post' indirectly signified that they need slimming products. When they are in the need of those products, their possibilities to response to the advertisement are high. That is why they were chosen as the informants of this study. Before they were selected as the informants, they were asked of their willingness to participate in this study. Auspiciously, all of them were excited to participate and they were then asked to gather at the researchers place.

There were 19 native advertisements of slimming products numbered from 1 to 19 . These advertisements were downloaded from Facebook and the hard copies were distributed to the informants. They were asked to look at all 19 advertisements and to choose only one that they have responded in Facebook among all advertisements. All informants were then asked to list down elements of the particular advertisement and to give their reasons for responding to the advertisement. Once everyone done for the first task, the informants were asked to put aside their chosen advertisement and to focus on other advertisements. They were then asked to choose the most unfavourable advertisement and to give reasons for choosing that particular advertisement. The data were analysed using constant comparison in which themes are determined based on the informants' answers.

\section{FINDINGS AND DisCUSSION}

\section{A. Elements of a Persuasive Native Advertisement for Slimming Products}

Based on the informants' favourable native advertisements, it is found that important elements to attract, to create interest, desire and to lead action towards the native advertisements are the unique headlines, the use of striking, contrasting colours for fonts and the background, the word 'repeat order', the comparative pictures (before and after picture), the testimonials, total weight reduced, and the call for action statements.

\section{B. How Native Advertisements for Slimming Products Lead to Action}

Most of the informants were attracted to read the body copy of the advertisements because of the unique headlines as well as the use of striking, contrasting colours for fonts and the background. Table I illustrates the headlines and colour usage in informants' favourable native advertisements.

It is found that the informants were influenced by the headlines because of their personality traits associated with their physical appearance. In general, people who aim to reduce their body weight would want immediate results. Therefore, the advertisers used the strategy of 'total weight reduced in days' so that the targeted audiences could see the 
effectiveness of the advertised products. These findings illustrated the positive impact of focusing persuasive messages on the personality traits as what has been found in [16].

TABLE I: HEADLINES AND COLOUR USAGE IN INFORMANTS' FAVOURABLE NATIVE ADVERTISEMENTS

\begin{tabular}{|c|c|c|}
\hline Ads no. & $\begin{array}{l}\text { Headlines (translated to } \\
\text { English) }\end{array}$ & Colour usage \\
\hline 1 & $\begin{array}{l}\text { "Niza has exhausted of being } \\
\text { fat" }\end{array}$ & $\begin{array}{l}\text { Font: Black } \\
\text { Background: Yellow }\end{array}$ \\
\hline 9 & $\begin{array}{l}\text { "Repeat order *because my } \\
\text { friend has reduced } 35 \mathrm{~kg} \text { " }\end{array}$ & $\begin{array}{l}\text { Font: Red and yellow } \\
\text { Background: Black }\end{array}$ \\
\hline 12 & $\begin{array}{l}\text { "Repeat order again because } 3 \\
\text { kg reduced in } 5 \text { days" }\end{array}$ & $\begin{array}{l}\text { Font: Black and red } \\
\text { Background: Yellow }\end{array}$ \\
\hline 19 & $\begin{array}{l}\text { "This is not a gimmick! I have } \\
\text { proven that I am not a } \\
\text { penguin! Reduced } 22 \mathrm{~kg} "\end{array}$ & $\begin{array}{l}\text { Font: Pink } \\
\text { Background: Black }\end{array}$ \\
\hline 15 & $\begin{array}{l}\text { "Without diet, } 5 \mathrm{~kg} \text { reduced in } \\
10 \text { days" }\end{array}$ & Font: Yellow and red \\
\hline 18 & " $8 \mathrm{~kg}$ reduced in 8 days" & $\begin{array}{l}\text { Background: Black } \\
\text { Font: Yellow } \\
\text { Background: Red }\end{array}$ \\
\hline
\end{tabular}

The first and the ninetieth advertisement on the other hand play with one's emotion by applying the slice-of-life strategy. People with weight problem are those who experience lower self-esteem and often being criticised among their family and friends. Informants who chose these two advertisements admitted that they actually felt so tired of others' discrimination towards them because of their physical appearance. These headlines were deemed by the informants as indirectly motivating the big-sized women to be like model in the advertisement. At the moment, the findings support statement in [9].

The informants also reported that the headlines might not be seen if there was no adequate attraction since native advertisements were integrated with so many contents. They stated that the contrasting colours were eye-catching and have led them to read the body copy of the advertisements. The powerful colour usage such as red, yellow and black seems to be the most essential element to create attention like what has been reported in [11].

For the most part, elements that have created informants' interest towards the advertised products are the testimonials and the word 'repeat order'. The testimonials came in the form of text box, Short Messaging Services (SMS) and Facebook discussions. Products' testimonials contained in the native advertisements were illustrated in Table II. All testimonials have shown positive product experience of the users. These product experiences have made the informants become interested towards the advertised products. The usage of the word 'repeat order' additionally has made them feel more excited because people would only repeat order when they feel satisfied with the product. The current findings supported findings in [13].

Most importantly, desirability towards the advertised products came when the informants see the comparative pictures of model before and after using the product. Although total weight reduced matters, the informants find that pictures prove everything. Most of the informants agreed that when the total weight reduced is associated with the comparative pictures, they immediately clicked 'like' on the product's Facebook page and commented "I want" to the advertisement like what has been directed in the advertisement. Apparently, the pictures impacted informants' brand attitude [11].

On the whole, these findings indicated that every element in the advertisements is important to lead the informants to seek for further details of the product. It shows the importance of the connectivity between the visual, the body copy and the headline in an advertisement as stated in [9]. The informants believe that a picture could reduce their uncertainties towards product's information in the advertisement. This has seemingly supported previous studies on pictures and relevancy of information in [9]-[11].

TABLE II: TESTIMONIALS

\begin{tabular}{ccc}
\hline $\begin{array}{c}\text { Ads } \\
\text { no. }\end{array}$ & \multicolumn{1}{c}{ Contents (translated to English) } & Form \\
\hline 1 & "I have experienced painful heels and feet, and it & Text box \\
& $\begin{array}{l}\text { was unbearable. After } 4 \text { times repeat order with } \\
A^{*}, \text { I loss 16 kg." }\end{array}$ &
\end{tabular}

9 “Okay. Thank you. I feel so excited to drink $A$ * because my friend has reduced her weight from $105 \mathrm{~kg}$ to $70 \mathrm{~kg}$ in 1 to 1 and a half month. That makes me jealous"

12 "Hi. My customer just went back from my house and bought $A^{*}$ and $B^{*}$ for second order. She said that she used other brand before this and reduced only $1 \mathrm{~kg}$ in a month. So, she tried both. $3 \mathrm{~kg}$ was reduced in only 5 days. In less than 1 month, she reduced another $5 \mathrm{~kg}$. She was so happy and willing to buy them at my house. I am happy for her. $A^{*}$ and $B^{*}$ are the best."

19 "People used to call me penguin just because I was fat. But everything has changed after I took $C^{*}$ for 3 months. It is true. I am not lying. You have to try. The result was amazing!"

15 "I feel like want to share on this wall. I finished a box of $A^{*}$ and 6 packets of $B^{*}$ and I was surprised that $I$ have reduced $5 \mathrm{~kg}$ and inches. The funniest thing was, I never went on diet. In fact, my appetite increases while consuming the products. It's just that I have to drink lots of water and take sweets whenever I feel dizzy."

18 "Hi! I have consumed $A^{*}$ and $B^{*}$ for 15 days. On the $8^{\text {th }}$ day, I found that my body weight has been reduced from $94 \mathrm{~kg}$ to $86.5 \mathrm{~kg}$. I'm so happy. Hope it reduces more."

SMS

Facebook wall discussion

Text box

Facebook wall discussion

Facebook wall discussion

* Represents slimming product's brand

\section{Elements that Obstruct the Persuasiveness of Native} Advertising

When the informants were asked on which elements of the native advertisements that could obstruct the persuasiveness of the message, the informants emphasize on the language of the message as well as the irrelevant picture usage.

The seventeenth advertisement for instance was unfavourable among the informants because of the provoking statements such as "Dumped by your boyfriend because of fat?", Afraid of being divorced because of fat?", "Body does not attractive like a virgin anymore?" and "Betrayed by husband because of fat?". These statements were deemed as harsh. The informants stated that the marketer should motivate the consumer, not to provoke. 
While looking at the advertisement, the informants admitted that they experienced lower self-esteem as their weaknesses in some way was gagged. In fact, the use of "Get this hottest and overselling product today!" statement in the same advertisement failed to persuade them to click on the advertisement to look for further details. Acceptable language therefore is important in persuasive message deliverance [15].

The informants also commented on the less believable pictures used in few advertisements. Pictures in the second, sixth, seventh and fourteenth advertisements were less attractive in which not much difference could be seen. These advertisements just displayed the models in different angles in order to make them slimmer. Most of the informants believe that honesty is a must in promoting products. Informant 10 for instance stated that, "Do not treat us like we do not know anything”. This finding supported previous study's finding on impact of deceptive advertising [18].

In other circumstances, the headline in the eighth advertisement was quite unique. However, informant 1 and 5 perceived it as unfavourable and unethical because the advertisement exposes women's uncovered body parts. They felt ashamed with the displayed pictures.

The usage of the Unique Selling Proposition (USP) in the tenth headline; "The tastiest fat burner juice" was doubted by most informants. Informant 3 suggested that the marketer should indicate who actually said that, not just claiming without being proven. Disclaimer should be stated although the advertisement is placed only to attract people to click on the product's Facebook page.

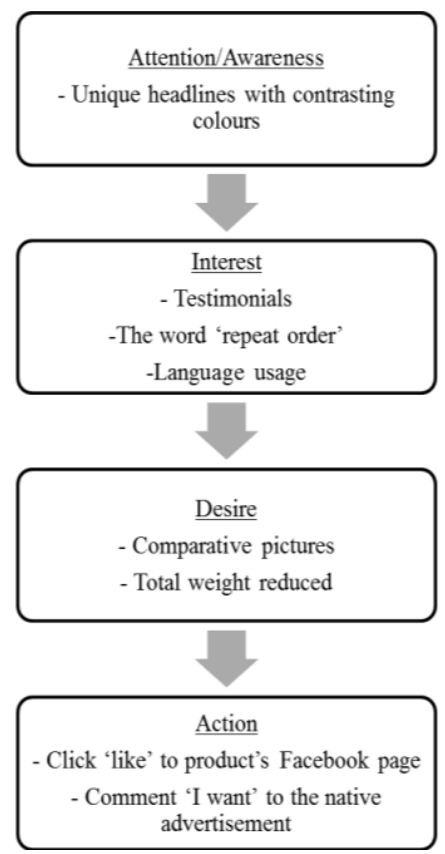

Fig. 1. The application of the AIDA model on slimming products' native advertisements.

\section{CONCLUSION}

The current findings indicated that the native advertisements need adequate elements to attract and change informants' attitude towards the advertised products. This is because native advertisements appear non-interruptive if compared to other online advertising strategies. This would lessen the potential of the native advertisement to be seen. Once the attention has been grabbed, advertiser should hold the consumer with impactful persuasive messages in order to make the consumers respond to the advertisement which subsequently will lead to purchasing behaviour.

Eventually, this study managed to construct a conceptual model associating the AIDA model and its applicability to slimming products' native advertisements. Fig. 1 illustrates the application of the AIDA model on slimming products' native advertisements.

\section{ACKNOWLEDGMENT}

Special thanks to the supportive informants who have contributed towards the completion of the paper. Also, to $\mathrm{Mr}$. Norsham Firdaus whom never fails to give his full cooperation in this study.

\section{REFERENCES}

[1] R. E. Petty and J. T. Cacioppo, Communication and persuasion: Central and Peripheral Routes to Attitude Change, New York: Springer-Verlag, 1986

[2] D. Greenberg. (June 2012). A framework for a $\$ 10 B+$ native advertising market. Techcrunch. [Online]. vol. 30. Available: http://www.techcrunch.com/2012/06/30/a-framework-for-the-10bnative-advertising-market/

[3] Google and Decipher. (August 2010). Increase brand favourability with promoted videos. Analysis of the impact of the Promoted Videos Format, [Online]. Available: http://www.thinkwithgoogle.com/insights/uploads/18606.pdf/downloa d/

[4] D. Greenberg. (September 2012). 4 Pro tips for publishers building a native ad strategy. Techcrunch. [Online]. vol. 2. Available: http://www.techcrunch.com/2012/09/02/4-pro-tips-for-publishersbuilding-a-native-ad-strategy/

[5] P. Holland. (December 2012). 10 marketing/advertising trends to focus on in 2013. Firebrand Ideas Ignition, [Online]. vol. 13. Available: $\quad$ http://www.blog.firebrandtalent.com/2012/12/10 marketing-advertising-trends-to-focus-on-in-2013/

[6] S. Faglio. (January 2012). Advertising: History of psychology attracting consumers. Business 2 community. [Online]. vol. 25. Available:

http://www.business2community.com/marketing/advertising-historyof-psychology-attracting-consumers-0123606

[7] E. S. Lewis and I. L. Preston, "The association model of the advertising communication process," Journal of Advertising, vol. 11, no. 2, pp. 3-15, 1982.

[8] Google, Youtube and Ipsos. (January 2012). TrueView Ads: Getting viewers to watch, not skip. U.S. [Online]. Available: http://www.thinkwithgoogle.com/insights/uploads/224352.pdf/downl oad/

[9] W. F. Arens, D. H. Schaefer, M. F. Weigold, and T. Holtzhausen, "Content analysis of roles portrayed by women in advertisements in selected South African media," Doctoral dissertation, University of Pretoria, 2010.

[10] L. Sullivan, Hey, Whipple, Squeeze This: A Guide to Creating Great Advertising, John Wiley and Sons, 2008.

[11] L. M. Scott, "Images in advertising: The need for a theory of visual rhetoric," Journal of Consumer Research, vol. 21, pp. 252-273, 1994.

[12] R. Blakeman, Integrated Marketing Communication: Creative Strategy from Idea to Implementation, Lanham, MD, Rowman and Littlefield Publishers, 2007.

[13] D. I. Hawkins and D. L. Mothersbaugh, Consumer Behavior: Building Marketing Strategy, Boston: McGraw-Hill Irwin, 2010, pp. 284.

[14] G. E. Belch and M. A. Belch, Advertising and Promotion: An Integrated Marketing Communication Perspective, New York, McGraw Hill/Irwin, 2008.

[15] T. E. Barry and D. J. Howard, "A review and critique of hierarchy of effects in advertising," International Journal of Advertising, vol. 9, no. 1, pp. 121-135, 1990.

[16] J. B. Hirsh, S. K. Kang, and G. V. Bodenhausen, "Personalized persuasion: tailoring persuasive appeals to recipients' personality 
traits,” Psychol Sci. vol. 23, no. 6, pp. 578-581, June 2012. DOI: $10.1177 / 0956797611436349$

[17] M. T. Bendixen, "Advertising effects and effectiveness," European Journal Marketing, vol. 127, no. 90, 1993.

[18] J. Cawley, R. Avery and M. Eisenberg, The effect of advertising and deceptive advertising on consumption: The case of over-the-counter weight loss products, Cornell University, New York, 2011.

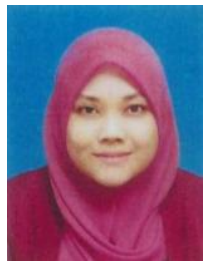

Hani Zulaikha Zulkifly received her bachelor's degree in Mass Communication (Broadcasting.) and Master of Mass Communication from the Universiti Teknologi Mara (UiTM), Malaysia in 2010 and 2012 respectively. At the moment, she is pursuing her $\mathrm{Ph}$. D in advertising ethics at the Universiti Malaya (UM) Malaysia. Earlier, she has worked as a video editor and as a part time lecturer. She has participated in several research works. Among them are 'Family cohesion and mobile phone involvement among secondary school children in Shah Alam', 'Language adaptation among migrant workers: The case of communication apprehension and miscommunication' and 'The potential of Malaysia's horror movies in creating critical minds: A never ending philosophical anecdote'. Primarily, her research interest centres on interpersonal and intercultural communication, advertising as well as broadcasting.

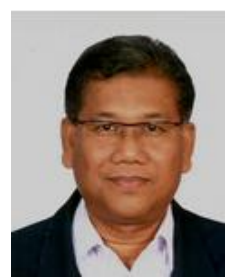

Norsham Firdaus earned his bachelor's degree in Mass Communication (Advertising) from Universiti Teknologi MARA (UiTM) in 1989 and Master of Science in Journalism from Ohio University in 1997. $\mathrm{He}$ has work experiences in the field of journalism, public relations, broadcasting, and book publishing. His past academic positions include as a coordinator of communication liberal courses, head of Journalism Programme, and head of Studies Centre for the mas communication flexible learning programme in UiTM. His interests in research are in the areas of communication apprehension, news representation, political communication, and social media. He is currently a lecturer at the Faculty of Communication and Media Studies, UiTM. 